\title{
Rozwiązania prawne dotyczące dyscypliny budżetowej i finansowej we Francji w świetle francuskiego kodeksu jurysdykcji finansowej
}

\author{
The Legal Solutions in the Field of Financial \\ and Budgetary Discipline in France in the Light \\ of the Code of Finance Jurisdiction
}

Streszczenie. Celem artykułu jest przedstawienie francuskich rozwiązań instytucjonalno-prawnych w przedmiocie dyscypliny finansów publicznych. Artykuł opisuje pozycję prawną i funkcjonowanie Trybunału Dyscypliny Budżetowej i Finansowej we Francji. Trybunał jest właściwy w sprawach poważnych naruszeń przepisów prawa finansowego. Jest on jednym z elementów systemu jurysdykcji w sprawach finansowych, stanowiącej wyspecjalizowany rodzaj sądownictwa administracyjnego. Aktem prawnym regulującym funkcjonowanie Trybunału, a także czyny stanowiące naruszenie dyscypliny finansów publicznych i kary, jest ustawa Kodeks jurysdykcji finansowej (Code des juridictions financières).

Słowa kluczowe: Francja; dyscyplina finansów publicznych; jurysdykcja finansowa. 


\begin{abstract}
The purpose of this article is to present French institutional and law solutions in the field of public finance discipline. The article describes legal position and functioning of Court of Budgetary and Finance Discipline in France. The jurisdiction of Court covers the cases of serious breach of public finance law. The Court is one of the elements of the system of jurisdiction in financial matters, that constitute a specialized type of administrative jurisdiction. The law that regulate the legal position and functioning of the Court, as well as the actes which are breaches of public finance discipline, and the sanctions for them, is the Code of finance jurisdiction (Code des juridictions financières).
\end{abstract}

Keywords: France; public finance discipline; financial judiciary.

\title{
1. Cel i przedmiot opracowania
}

Polskie prawo przewiduje szczególny rodzaj odpowiedzialności, jaką jest odpowiedzialność za naruszenie dyscypliny finansów publicznych. Odpowiedzialność ta jest oceniana jako specyficzna, posiadająca własny przedmiot, którym jest ochrona prawidłowości gospodarowania środkami publicznymi, a zarazem zawierająca rozwiązania prawne „z pogranicza” innych rodzajów odpowiedzialności, takich jak odpowiedzialność administracyjna, pracownicza czy karna ${ }^{1}$. Istniejący model odpowiedzialności za naruszenie dyscypliny finansów publicznych jest kwestionowany w nauce polskiego prawa finansowego ${ }^{2}$.

Stan prawny w Polsce w przedmiotowej kwestii stanowi inspirację do badań rozwiązań prawnych na ten temat funkcjonujących we Francji. Regulacje polskie pod wieloma względami są podobne do francuskich, te ostatnie przewidują jednak specyficzne rozwiązania w sprawach dotyczących dyscypliny finansów publicznych. Rozwiązania te mogą być interesujące z polskiego punktu widzenia, gdyż odnaleźć w nich można podobne intencje ustawodawcy dotyczące ochrony prawidłowości prowadzenia publicznej gospodarki finansowej, a także podobne problemy, jakie stwa-

\footnotetext{
A. Borodo, Polskie prawo finansowe. Zarys ogólny, Toruń 2010, s. 76.

M.in. C. Kosikowski, Istota dyscypliny finansów publicznych i odpowiedzialności za jej naruszenie, [w:] C. Kosikowski, E. Ruśkowski (red.), Finanse publiczne i prawo finansowe, Warszawa 2008, s. 820-821.
} 
rza przyjęty model odpowiedzialności za naruszenie dyscypliny finansów publicznych.

Celem opracowania jest przedstawienie organizacji i działania Trybunału (Sądu) Dyscypliny Budżetowej i Finansowej, stanowiącego główny element systemu instytucjonalnego jurysdykcji w sprawach finansowych we Francji i wybranych problemów prawnych jurysdykcji w sprawach budżetowych i finansowych.

\section{Podstawy prawne i system organizacyjny jurysdykcji w sprawach finansowych we Francji}

Podstawowym aktem prawnym regulującym zasady odpowiedzialności za naruszenie norm prawa finansowego we Francji jest ustawa Kodeks jurysdykcji finansowej (Code des juridictions financières) ${ }^{3}$.

Kodeks ustanawia system jurysdykcji w sprawach finansowych. Określa organizację i kompetencje poszczególnych organów tworzących ten system, a także rodzaje naruszeń i kary za naruszenie przepisów prawa finansowego.

Na organizację organów orzekających w sprawach finansowych składają się: Trybunał Obrachunkowy (la Cour des comptes, dalej: Trybunał Obrachunkowy, TO), regionalne izby obrachunkowe (les chambres régionales des comptes), terytorialne izby obrachunkowe (les chambres territoriales des comptes), Trybunał Dyscypliny Budżetowej i Finansowej (Cour de discipline budgétaire et financière, dalej: Trybunał, TDBF), a także inne organy, takie jak Stała Komisja do Spraw Kontroli Organizacji Zbiorowego Zarządzania Prawami Autorskimi (Commission permanente de contrôle des sociétés de perception et de répartition) oraz Rada do Spraw Opłat Obowiązkowych (Conseil des prélèvements obligatoires $)^{4}$. 
Głównym elementem systemu kontroli i jurysdykcji finansowej jest Trybunał Obrachunkowy. Posiada on kompetencje kontrolne i jurysdykcyjne. Jest on właściwy w sprawach rachunków prowadzonych przez księgowych publicznych, z wyjątkiem spraw przekazanych z mocy Kodeksu w pierwszej instancji regionalnym i terytorialnym izbom obrachunkowym. Trybunał Obrachunkowy podejmuje decyzje w sprawach odwołań od orzeczeń wydawanych przez regionalne izby obrachunkowe oraz terytorialne izby obrachunkowe. Konstytucja Francji ${ }^{5}$ w art. 47-2 wskazuje, że zadaniem TO jest wspieranie Parlamentu w kontroli działań rządu. TO wspiera Parlament i rząd w kontroli wykonywania ustaw finansowych i w stosowaniu ustaw o finansowaniu ubezpieczeń społecznych oraz w ocenie polityk publicznych. Pełni także funkcję informacyjną poprzez publikowanie raportów. Trybunał weryfikuje, w ramach kontroli dokumentacyjnej oraz kontroli na miejscu, prawidłowość realizacji dochodów i wydatków opisanych w rachunkowości publicznej i prawidłowego wykorzystania środków, którymi zarządzają służby państwowe oraz inne osoby prawne prawa publicznego (art. L111-3 Kodeksu). Uprawnienia kontrolne TO przypominają uprawnienia kontrolne Najwyższej Izby Kontroli w Polsce.

Regionalne izby obrachunkowe sprawują kontrolę rachunków prowadzonych przez księgowych publicznych w jednostkach samorządu terytorialnego oraz samorządowych instytucjach publicznych, a także takich rachunków prowadzonych przez osoby, które określane są jako księgowi de facto (tzn. nie będące księgowymi publicznymi, ale faktycznie wykonujące zadania takie, jak księgowi publiczni).

Terytorialne izby obrachunkowe działają we francuskich terytoriach zależnych.

Przy Trybunale Obrachunkowym działa Trybunał Dyscypliny Budżetowej i Finansowej. Zadaniem TDBF jest orzekanie w sprawach osób, które dopuściły się czynów stanowiących naruszenie norm ustawy Kodeks jurysdykcji finansowej.

5 Journal Officiel nr 0238 z 5 października 1958, s. 9151, http://www.legifrance.gouv.fr. 


\section{Trybunał Dyscypliny Budżetowej i Finansowej}

Trybunał Dyscypliny Budżetowej i Finansowej utworzono w 1948 r. na mocy ustawy z dnia 25 września $1948^{6}$. Obecnie jego funkcjonowanie regulują przepisy art. L311-1 - L316-1, stanowiące księgę III Kodeksu jurysdykcji finansowej. Trybunał ten jest organem właściwym w sprawach naruszeń prawa finansowego przez osoby fizyczne. Wskazuje się, że jego działalność nie ma charakteru właściwego dla jurysdykcji cywilnej, której celem jest zasądzenie poszkodowanej wspólnocie terytorialnej odpowiedniego odszkodowania. Działalność Trybunału ma charakter represyjny i wiąże się z nakładaniem grzywien o charakterze administracyjnym $^{7}$.

Od orzeczeń Trybunału nie przysługuje odwołanie. Służy od nich kasacja do Rady Stanu (Conseil d'État). Istnieje także możliwość wznowienia postępowania w drodze rewizji. Wskazuje się, że działalność Trybunału ewoluuje w kierunku orzekania w sprawach poważniejszych uchybień w zarządzaniu środkami publicznymi ${ }^{9}$.

Trybunał składa się proporcjonalnie z sędziów Trybunału Obrachunkowego i członków Rady Stanu.

W skład Trybunału wchodzą:

- $\quad$ Pierwszy prezes Trybunału Obrachunkowego, który mu przewodniczy;

- $\quad$ prezes sekcji finansów Rady Stanu, jako wiceprezes;

- członkowie wybierani w równej liczbie spośród członków Trybunału Obrachunkowego i członków Rady Stanu, mianowanych na pięć lat przez dekret wydany przez Radę Ministrów.

6 http://www.ccomptes.fr/Nos-activites/Cour-de-discipline-budgetaire-et-financiere-CD BF/Fonctionnement (dostęp: 10 grudnia 2013 r.).

7 La Cour des comptes, éd. Centre National de la Recherche Scientifique, Paris 1984, s. 908.

8 Rada Stanu jest organem opiniującym projekty aktów prawnych (art. 37 i n. Konstytucji francuskiej), a także jest najwyższym organem sądownictwa administracyjnego (art. L111-1 Kodeksu sądownictwa administracyjnego (Code de justice administrative).

$9 \quad$ La Cour des comptes..., s. 917, 919. 
Trybunał Dyscypliny Budżetowej i Finansowej ma swoją siedzibę w tym samym miejscu, w którym ma siedzibę Trybunał Obrachunkowy. Służby TO prowadzą sekretariat Trybunału Dyscypliny Budżetowej i Finansowej.

\section{Osoby ponoszące odpowiedzialność przed Trybunałem Dyscypliny Budżetowej i Finansowej}

Określenie kręgu osób odpowiedzialnych za naruszenie przepisów dotyczących zarządzania środkami publicznymi od dawna napotykało wiele trudności ${ }^{10}$. Krąg ten dotyczy osób pełniących m.in. określone funkcje polityczne, zwłaszcza ministrów. Próby objęcia ich jurysdykcją finansową za naruszenie przepisów dotyczących zarządzania środkami publicznymi budziły wątpliwości dotyczące możliwości ingerowania w ich kompetencje decyzyjne i oceny podejmowanych działań ${ }^{11}$.

Ustawa z 1948 r. powołująca Trybunał rozwiązała ten problem, wskazując jako osoby ponoszące odpowiedzialność przed TDBF szeroki krąg funkcjonariuszy państwowych, samorządowych i innych osób, z wyłączeniem jednak osób posiadających władzę polityczną ${ }^{12}$.

Osoby ponoszące odpowiedzialność przed Trybunałem wskazane są obecnie w art. L312-1 i L312-2 Kodeksu jurysdykcji finansowej. Są to:

a. osoby wchodzące w skład gabinetów członków rządu (z wyjątkiem samych członków rządu);

b. funkcjonariusze cywilni i wojskowi państwa, jednostek samorządu terytorialnego, a także państwowych i samorządowych instytucji publicznych oraz związków jednostek samorządu terytorialnego;

c. inne osoby reprezentujące, kierujące lub działające na rzecz innych podmiotów niż wyżej wymienione, o ile podmioty te podlegają kon-

\footnotetext{
10 Pojawiły się one już w czasie Rewolucji Francuskiej. Ewolucja prawa w tym zakresie przedstawiona jest w: La Cour des comptes..., s. 897-905, 912-914.

11 La Cour des comptes..., s. 879-905.

12 Tamże, s. 907, 914.
} 
troli TO, regionalnej izby obrachunkowej lub terytorialnej izby obrachunkowej;

a także osoby faktycznie wykonujące funkcje osób wymienionych powyżej.

Odpowiedzialności przed Trybunałem nie ponoszą natomiast, w związku z działaniami podejmowanymi w związku z pełnioną funkcją:

a. członkowie rządu;

b. przewodniczący rad regionów i rad departamentów;

c. przewodniczący zarządu Korsyki;

d. merowie;

e. pochodzący z wyboru przewodniczący związków jednostek samorządu terytorialnego;

f. przewodniczący rządu Nowej Kaledonii i przewodniczący zgromadzenia tej prowincji, Prezydent Polinezji Francuskiej, przewodniczący rady generalnej la Mayotte, przewodniczący rad terytorialnych Saint-Barthelémy, Saint-Martin oraz Saint-Pierre-et-Miquelon.

Osoby te nie podlegają odpowiedzialności przed TDBF w zakresie pełnionych przez siebie funkcji. Mogą one jednak (z wyjątkiem członków rządu) na zasadzie wyjątku podlegać odpowiedzialności przed Trybunałem w niektórych przypadkach, m.in. w przypadku popełnienia określonych czynów ${ }^{13}$, a także w przypadku wydania podwładnemu polecenia dokonania określonego działania z naruszeniem art. L313-6 Kodeksu ${ }^{14}$.

W określonych przypadkach odpowiedzialności przed Trybunałem nie ponoszą także ${ }^{15}$ :

13 Np. doprowadzenie swoim działaniem do ukarania osoby prawnej prawa publicznego lub podmiotu prawa prywatnego odpowiedzialnego za zarządzanie usługami publicznymi wskutek niewykonania orzeczenia sądowego (art. L313-7 Kodeksu).

14 Sankcjonującym dostarczenie, z naruszeniem swoich obowiązków wykonywanych w ramach pełnionej funkcji, innej osobie nieuzasadnionej korzyści, pieniężnej lub rzeczowej, powodującej szkodę Skarbu Państwa, wspólnoty samorządowej lub innego podmiotu, a także próbę dostarczenia takiej korzyści.

15 Osoby wymienione $\mathrm{w}$ lit. a-i nie ponoszą odpowiedzialności przed Trybunałem, gdy działają w granicach wskazanych w Kodeksie przepisów odrębnych lub z upoważnienia osób nie podlegających co do zasady odpowiedzialności przed Trybunałem. W pozostałym zakresie ponosić mogą jednak odpowiedzialność przed TDBF. Osoby wymienione $w$ lit. j-k nie ponoszą odpowiedzialności, o ile działają bez wynagrodzenia i jeśli nie pełnią funkcji przewodniczącego. $\mathrm{W}$ przypadku, gdy są one wynagradzane 
a. wiceprzewodniczący i inni członkowie rady regionu;

b. wiceprzewodniczący i inni członkowie rady departamentu;

c. zastępcy merów i inni członkowie rady miejskiej;

d. wiceprzewodniczący i inni członkowie organu stanowiącego związku jednostek samorządu terytorialnego;

e. pochodzące z wyboru osoby zarządzające instytucjami zabezpieczenia społecznego podlegającymi kontroli Trybunału Obrachunkowego i działające w granicach odpowiednich przepisów - o ile są nie wynagradzane i nie wykonują (bezpośrednio lub z upoważnienia) funkcji przewodniczącego;

f. osoby zarządzające lub działające na rzecz instytucji charytatywnych poddanych kontroli Trybunału Obrachunkowego lub regionalnej izby obrachunkowej - o ile nie są wynagradzane i nie wykonują funkcji przewodniczącego;

g. inne osoby.

Osoby ponoszące odpowiedzialność przed Trybunałem nie podlegają jednak żadnym sankcjom, o ile przedstawią pisemne polecenie dokonania danego działania wydane przez zwierzchnika lub osobę upoważnioną na podstawie właściwych przepisów do wydania takiego polecenia. Odpowiedzialność osoby wydającej polecenie zastępuje w takim wypadku odpowiedzialność osoby wykonującej polecenie. Polecenie może być także wydane osobiście przez właściwego ministra. Odpowiedzialność osób wydających polecenie zastępuje odpowiedzialność osoby je wykonującej od momentu, w którym osoby wydające polecenie zostały należycie poinformowane o sprawie. Zasadę tę stosuje się również do funkcjonariuszy jednostek samorządu terytorialnego i osób działających na rzecz tych jednostek i ich związków (art. L313-9 i art. L313-10 Kodeksu).

Krąg osób ponoszących odpowiedzialność przed Trybunałem obejmuje głównie urzędników administracji rządowej i samorządowej wykonujących budżet. W niektórych sytuacjach odpowiedzialność mogą pono-

oraz gdy pełnią funkcję przewodniczącego, podlegają odpowiedzialności przed Trybunałem. Intencją tych przepisów było ograniczenie odpowiedzialności osób wykonujących daną funkcję bezpłatnie, na zasadzie wolontariatu, aby nie osłabiać ich zapału. $L a$ Cour des comptes..., s. 913. 
sić inne osoby, np. merowie, przewodniczący organów stanowiących samorządu i inne osoby, które wydają podwładnemu pisemne polecenie dokonania danego działania i które ponoszą wówczas odpowiedzialność zamiast podwładnego, który działania dokonał. Z brzmienia art. L312-1 i L313-9 Kodeksu wynika, że przed Trybunałem nie ponoszą odpowiedzialności członkowie rządu.

\section{Rodzaje czynów (naruszeń) i kar}

Czyny podlegające odpowiedzialności określają art. L313-1 do L313-7-1 Kodeksu. Mają one głównie charakter naruszeń związanych z wykonywaniem budżetu państwa lub budżetów lokalnych. Są to takie czyny (popełnione przez osoby podlegające odpowiedzialności przed Trybunałem), jak:

- dokonanie wydatku bez zachowania zasad kontroli finansowej dotyczących angażowania środków publicznych;

- $\quad$ nieprawidłowe księgowanie wydatków w celu ukrycia przekroczenia limitu wydatków;

- dokonanie wydatku bez podstawy prawnej lub bez otrzymania stosownego upoważnienia;

- $\quad$ inne przekroczenie zasad dotyczących realizacji dochodów i wydatków państwa, jednostek samorządu terytorialnego, instytucji i podmiotów publicznych lub podczas zarządzania mieniem tych podmiotów, a także wyrażenie zgody przez osoby odpowiedzialne za nadzór nad takimi podmiotami na dokonanie niezgodnej z prawem decyzji;

- $\quad$ świadome niepodpisanie przez osobę w ramach wykonywanej funkcji dokumentów, które jest ona zobowiązana dostarczyć organom podatkowym zgodnie z przepisami Kodeksu ogólnego podatkowego lub aneksów do niego, a także świadome dostarczenie dokumentów błędnych lub niekompletnych;

- dostarczenie, z naruszeniem swoich obowiązków wykonywanych w ramach pełnionej funkcji podstawowej lub dodatkowej, innej osobie nieuzasadnionej korzyści pieniężnej lub rzeczowej, powodującej 
szkodę Skarbu Państwa, wspólnoty samorządowej lub innego podmiotu, a także próba dostarczenia takiej korzyści;

- spowodowanie swoim działaniem ukarania osoby prawnej prawa publicznego lub podmiotu prawa prywatnego odpowiedzialnego za zarządzanie usługami publicznymi wskutek niewykonania (w całości lub w części) lub wykonania z opóźnieniem orzeczenia sądowego;

- wyrządzenie przez osoby działające w podmiotach takich jak państwo, samorządy i ich związki oraz podmioty samorządowe, w ramach pełnionej funkcji, poważnej szkody tym podmiotom, poprzez działanie stojące w oczywistej sprzeczności z interesem tych podmiotów, poprzez poważne uchybienia w wypełnianiu obowiązków kontrolnych lub poprzez powtarzające się zaniechania lub zaniedbania w wypełnianiu obowiązków kierowniczych.

Sankcjami za popełnienie wyżej wymienionych czynów są grzywny. Wysokość grzywien wynosi co do zasady od 150 euro do kwoty stanowiącej równowartość rocznego wynagrodzenia brutto danej osoby, w wysokości obowiązującej w dniu popełnienia czynu ${ }^{16}$. W niektórych przypadkach wobec osób, które otrzymują świadczenia niebędące wynagrodzeniem, wysokość grzywny ustala się według rocznego wynagrodzenia brutto odpowiadającego najwyższemu wynagrodzeniu związanemu ze stanowiskiem dyrektora w administracji centralnej. Wysokość kar orzekanych przez Trybunał została ustalona jako mieszcząca się w określonych przedziałach kwotowych. Trybunał może różnicować wymiar kary z uwzględnieniem okoliczności sprawy, w tym stopnia szkodliwości czy-

16 W przypadku czynów z art. L313-6 (dostarczenie innej osobie nieuzasadnionej korzyści powodującej szkodę Skarbu Państwa lub samorządu) oraz z art. L313-7 (doprowadzenie do ukarania osoby prawnej prawa publicznego wskutek niewykonania lub wykonania z opóźnieniem wyroku sądu) minimalna wysokość grzywny wynosi 300 euro. W przypadku czynu z art. L313-6 maksymalna wysokość grzywny wynosi dwukrotność kwoty stanowiącej równowartość rocznego wynagrodzenia brutto danej osoby w wysokości obowiązującej w dniu popełnienia czynu. W przypadku, gdy odpowiedzialność przed Trybunałem ponoszą: przewodniczący organów stanowiących samorządów i radni, merowie, przewodniczący rad regionów i rad departamentów i inne, o których mowa w art. L312-2, maksymalna wysokość grzywny wynosi 750 euro lub roczna wysokość diety przyznanej im w dniu popełnienia czynu, jeżeli jest wyższa od 750 euro (art. L313-13). 
nu czy stopnia zawinienia sprawcy. Niektóre czyny w postaci działania lub zaniechania stanowią naruszenie przepisów Kodeksu tylko wtedy, o ile są popełnione świadomie (np. art. L313-5 mówi o świadomym niepodpisywaniu dokumentów).

Orzeczenia skazujące wydawane przez Trybunał mogą na mocy decyzji samego Trybunału podlegać publikacji w Dzienniku Urzędowym Republiki Francuskiej w formie papierowej i elektronicznej. Publikacji podlegają orzeczenia ostateczne.

W odróżnieniu od obowiązującej w Polsce ustawy o odpowiedzialności za naruszenie dyscypliny finansów publicznych, regulującej w sposób kazuistyczny czyny podlegające odpowiedzialności, Kodeks wymienia kilka czynów, wskazując ich znamiona. Znamiona czynów określonych w artykule L313-1-7-1 Kodeksu ${ }^{17}$ mogą mieć inne czyny, stanowiące naruszenie innych niż Kodeks ustaw (np. prawa zamówień publicznych).

\section{Postępowanie przed Trybunałem Dyscypliny Budżetowej i Finansowej}

Procedura przed Trybunałem zawiera pewne elementy przypominające procedurę karną oraz administracyjną ${ }^{18}$.

Wniosek o skierowanie sprawy do Trybunału Dyscypliny Budżetowej i Finansowej składany jest za pośrednictwem prokuratury. Zgodnie z art. L314-1 Kodeksu z wnioskiem o skierowanie sprawy do Trybunału mogą wystąpić wyłącznie:

- przewodniczący Zgromadzenia Narodowego;

- przewodniczący Senatu;

- Premier;

- minister właściwy do spraw finansów;

17 Np. orzeczenie z 11 października 2013 r. nr 191-701 w sprawie międzygminnego domu starców w Champcevrais «Maison de retraite intercommunale de Champcevrais» http://www.ccomptes.fr/fr../Publications/Publications/Maison-de-retraite-intercom munale-de-Champcevrais (dostęp: 11 grudnia 2013 r.).

18 La Cour des comptes..., s. 910. 
- inni członkowie rządu w sprawach dotyczących funkcjonariuszy i osób działających w ich imieniu;

- Trybunał Obrachunkowy;

- Prokurator Generalny przy Trybunale Obrachunkowym (na wniosek wymienianych wyżej organów lub z własnej inicjatywy);

- regionalne i terytorialne izby obrachunkowe;

- osoby wskazane w odrębnych przepisach.

Nie można skierować sprawy do Trybunału, jeżeli upłynęło 5 lat od dnia popełnienia czynu mogącego podlegać sankcjom przewidzianym w przepisach legislacyjnych Kodeksu o Trybunale Dyscypliny Budżetowej i Finansowej (Księga III, Tytuł I).

Po skierowaniu wniosku do TDBF za pośrednictwem prokuratury, Prokurator Generalny bada wniosek i decyduje o nadaniu mu dalszego biegu. Jeżeli Prokurator Generalny uzna, że nie ma podstaw do wszczęcia postępowania, umarza sprawę. W przeciwnym przypadku przekazuje akta sprawy przewodniczącemu Trybunału Dyscypliny Budżetowej i Finansowej, który wyznacza sprawozdawcę odpowiedzialnego za przeprowadzenie dochodzenia ${ }^{19}$. Dochodzenie na tym etapie może być prowadzone przeciwko osobie nie wskazanej imiennie.

Sprawozdawca w ramach prowadzenia dochodzenia ma prawo dokonywać czynności takich jak: zbieranie materiałów, wnioskowanie o udostępnienie żądanych dokumentów (także poufnych) przesłuchiwania ustnego lub w formie pisemnej wszelkich świadków i wszelkich innych osób, które mogły dopuścić się naruszeń. Osoby, w stosunku do których zostały ujawnione fakty mogące stanowić podstawę do postawienia ich przed Trybunałem, są zawiadamiane przez prokuraturę listem poleconym za potwierdzeniem odbioru, informującym o prawie do skorzystania w dalszym postępowaniu z pomocy prawnej. Gdy dochodzenie jest zakończone, Prokurator Generalny może zdecydować o umorzeniu sprawy, jeżeli uzna, że nie ma podstaw do oskarżenia. Jeżeli postępowanie jest

19 Zgodnie z art. R311-3 Kodeksu sprawozdawcę powołuje premier na wniosek przewodniczącego Trybunału spośród członków Rady Stanu, Trybunału Obrachunkowego, trybunałów administracyjnych i administracyjnych sądów odwoławczych oraz regionalnych i terytorialnych izb obrachunkowych. 
kontynuowane, o sprawie jest informowany minister lub inny organ, któremu podlega osoba, w stosunku do której postępowanie się toczy, a także minister właściwy do spraw finansów oraz, w razie potrzeby, minister sprawujący nadzór nad państwowymi i samorządowymi instytucjami publicznymi. Te organy przedstawiają swoje opinie w terminie ustalonym przez przewodniczącego Trybunału, nie krótszym niż miesiąc. Nieprzedstawienie opinii w terminie nie stanowi przeszkody do kontynuowania postępowania (art. L314-4 oraz L314-5 Kodeksu).

Następnie akta sprawy są ponownie przekazywane Prokuratorowi Generalnemu, który podejmuje decyzję o umorzeniu postępowania wraz z uzasadnieniem lub o jego kontynuowaniu. W tym drugim przypadku kieruje on sprawę do Trybunału wraz z wnioskami i ich uzasadnieniem.

Decyzja Prokuratora Generalnego o umorzeniu postępowania jest notyfikowana przewodniczącemu Zgromadzenia Narodowego, Prezydentowi, przewodniczącemu Senatu, Premierowi, zainteresowanemu ${ }^{20}$, ministrowi, któremu podlega zainteresowany, ministrowi finansów, a także, w razie potrzeby, ministrowi właściwemu w sprawach nadzoru nad instytucjami publicznymi oraz autorowi skargi do TDBF.

Zainteresowany (obwiniony) ma możliwość zapoznania się z aktami obejmującymi pełny materiał zgromadzony w sprawie wraz z wnioskami Prokuratora Generalnego. Ma on także możliwość przedstawienia swojego stanowiska na piśmie, osobiście lub przez swojego przedstawiciela, w terminie jednego miesiąca od dnia zapoznania się z aktami sprawy.

Kolejny etap postępowania wiąże się z przeprowadzeniem rozprawy przed Trybunałem Dyscypliny Budżetowej i Finansowej.

Sprawozdawca sporządza pisemny raport, po odczytaniu którego zainteresowany, osobiście lub przez przedstawiciela, jest wzywany do przedstawienia swojego stanowiska. Prokurator Generalny, adwokat generalny lub komisarz rządowy przedstawiają swoje wnioski. Pytania zainteresowanemu lub jego pełnomocnikowi może zadawać przewodniczący lub, za jego zgodą, członkowie Trybunału. Zainteresowany powinien mieć „ostatnie słowo” podczas rozprawy.

20 Pojęcie „zainteresowany” oznacza osobę, przeciwko której toczy się postępowanie. 
Osoby składające wyjaśnienia przed Trybunałem składają przysięgę na zasadach określonych w Kodeksie procedury karnej. Na uzasadniony wniosek zainteresowany lub osoby składające wyjaśnienia mogą być zwolnione od obowiązku osobistego stawiennictwa na rozprawie.

Orzeczenia zapadają większością głosów. W przypadku równej liczby głosów decyduje głos przewodniczącego. Orzeczenia Trybunału są zaopatrzone w klauzulę wykonalności. Nie przysługuje od nich apelacja. Jednak mogą być one przedmiotem kasacji do Rady Stanu. Ten środek odwoławczy może wnieść zainteresowany lub Prokurator Generalny.

Istnieje także możliwość wznowienia postępowania w drodze rewizji orzeczenia w przypadku, gdy wyjdą na jaw nowe fakty lub ujawnione zostaną dokumenty, z których wynikać może brak odpowiedzialności zainteresowanego.

Trybunał przedstawia każdego roku Prezydentowi Republiki raport ze swej działalności. Raport ten jest dołączany do raportu Trybunał Obrachunkowego i publikowany w Dzienniku Urzędowym Republiki Francuskiej.

\section{Odpowiedzialność za naruszenie dyscypliny finansowej i budżetowej a inne rodzaje odpowiedzialności}

W świetle Kodeksu jurysdykcji finansowej odpowiedzialność z tytułu naruszenia norm prawa budżetowego i finansowego może zbiegać się z innymi rodzajami odpowiedzialności, takimi jak odpowiedzialność dyscyplinarna i odpowiedzialnością karna. Istotne regulacje zawiera art. L314-18 Kodeksu, zgodnie z którym postępowanie przed Trybunałem Dyscypliny Budżetowej i Finansowej nie stanowi przeszkody w prowadzeniu postępowania karnego oraz postępowania dyscyplinarnego.

Jeżeli dochodzenie pozwala na postawienie zarzutów osobie wymienionej w art. L312-1 Kodeksu w sprawie faktów, których natura wskazuje na możliwość zastosowania sankcji dyscyplinarnych, przewodniczący Trybunału zawiadamia o tych faktach organ mający władzę dyscyplinarną 
nad zainteresowanym. Ten organ, w terminie 6 miesięcy, zawiadamia przewodniczącego Trybunału o podjętych przez siebie środkach.

W przypadku, gdy w wyniku dochodzenia ujawnione zostaną czyny stanowiące przestępstwo, Prokurator Generalny przesyła akta sprawy Prokuratorowi Republiki na zasadach określonych w przepisach Kodeksu procedury karnej i zawiadamia o tym ministra lub inny organ, któremu podlega zainteresowany.

W przypadku, gdy Trybunał Obrachunkowy w ramach swojej działalności ujawnił czyny, w sprawie których nie została skierowana skarga do Trybunału Dyscypliny Budżetowej i Finansowej lub które nie stanowią dostatecznej podstawy do zastosowania sankcji przez TDBF, ale które spowodowały jednak przekroczenie limitu wydatków lub spowodowały szkodę na rzecz podmiotów wymienionych w art. L312-1 (państwo, samorządy, instytucje publiczne), ministrowie lub organy odpowiedzialne są zobowiązane do wszczęcia postępowania dyscyplinarnego przeciwko osobom wymienionym w art. L312-1, które dopuściły się tych czynów. Sankcje zastosowane w tym trybie są podawane do wiadomości Parlamentu.

Z powyższych regulacji wynika, że ten sam czyn może stanowić jednocześnie czyn podlegający sankcji określonej w Kodeksie jurysdykcji finansowej i jednocześnie czyn podlegający sankcjom dyscyplinarnym lub karnym. Organ, który jest właściwy w sprawach odpowiedzialności dyscyplinarnej osoby postawionej przed TDBF, informuje TDBF o środkach, jakie podjął wobec tej osoby. Z orzecznictwa TDBF wynika, że wymierzone danej osobie sankcje dyscyplinarne lub karne są brane pod uwagę przy wymiarze kary przez Trybunał Dyscypliny Budżetowej i Finansowej $^{21}$.

21 Np. orzeczenie z dnia 15 lipca 2013 r. nr 190-661 w sprawie Biura Poczty i Telekomunikacji w Polinezji Francuskiej «Office des postes et télécommunications de la Polynésie française» http://www.ccomptes.fr/fr../Publications/Publications/Office-despostes-et-telecommunications-de-la-Polynesie-francaise (dostęp: 11 grudnia 2013 r.). 


\section{Podsumowanie}

Francuski Kodeks jurysdykcji finansowej reguluje działalność organów właściwych w sprawach z zakresu naruszenia norm z dziedziny finansów publicznych, wyodrębniając osobną kategorię jurysdykcji finansowej, stanowiącej wyspecjalizowany rodzaj jurysdykcji administracyjnej. Tego rodzaju regulacji, poświęconej jurysdykcji administracyjnej w sprawach finansowych, a zwłaszcza budżetowych, nie przewidziano w polskim ustawodawstwie, w którym nie ma odrębnego sądownictwa finansowego. Polskie organy posiadające funkcje kontrolne i nadzorcze (jak np. regionalne izby obrachunkowe), nie mają kompetencji sądowniczych, nie są sądami.

Orzekanie w sprawach finansowych w Polsce jest - w określonym zakresie (np. skarga do WSA na rozstrzygnięcie regionalnej izby obrachunkowej) - wykonywane przez sądy administracyjne (WSA, NSA).

Nie ma jednak odrębnych sądów wyspecjalizowanych tylko w sprawach finansowych. Organy takie jak francuskie regionalne izby obrachunkowe, terytorialne izby obrachunkowe czy Trybunał Obrachunkowy posiadają natomiast zarówno kompetencje związane z kontrolą rachunków prowadzonych przez księgowych publicznych, kontrolą gospodarki finansowej podmiotów korzystających ze środków publicznych, jak i kompetencje o charakterze jurysdykcyjnym.

Trybunał Dyscypliny Budżetowej i Finansowej stanowi niemający bezpośredniego odpowiednika w polskich rozwiązaniach prawnych przykład instytucji o charakterze sądowym, orzekającej w sprawach będących - w polskim porządku prawnym - odpowiednikiem naruszenia dyscypliny finansów publicznych.

W regulacjach prawa polskiego dostrzec można pewne podobieństwa do rozwiązań francuskich, związane z istnieniem szczególnego rodzaju odpowiedzialności, jaką stanowi odpowiedzialność za naruszenie dyscypliny finansów publicznych, określeniem kręgu osób ponoszących taką odpowiedzialność czy rodzaju czynów mogących stanowić naruszenie dyscypliny finansów publicznych. Instytucją, do której można by w Polsce porównywać francuski Trybunał, jest Główna Komisja Orzekająca 
w Sprawach o Naruszenie Dyscypliny Finansów Publicznych, która jednak mieści się w obszarze organów administracyjnych, od decyzji których przysługuje odwołanie do sądu administracyjnego.

Inną dostrzegalną różnicą w regulacjach polskich i francuskich jest sposób określenia czynów podlegających odpowiedzialności za naruszenie dyscypliny finansów publicznych. Polska ustawa o odpowiedzialności za naruszenie dyscypliny finansów publicznych może być oceniona pod tym względem jako niezwykle kazuistyczna, w porównaniu do Kodeksu jurysdykcji finansowej we Francji ${ }^{22}$. Ten ostatni wymienia i opisuje czyny (których jest kilka, a nie kilkanaście czy kilkadziesiąt, jak w ustawie polskiej $)^{23}$.

Polskie rozwiązania prawne nie mogą, z uwagi na różnice ustrojowe czy dotyczące organizacji wymiaru sprawiedliwości, być porównywane do regulacji francuskich. Jednak wskazuje się, że powielają one niektóre ich wady. Związane są one m.in. z obserwowaną zarówno w Polsce, jak i we Francji niską efektywnością działania organów właściwych w sprawach dyscypliny finansów publicznych. W Polsce wyraża się to m.in. w niewielkim odsetku osób ukaranych w stosunku do liczby wszczętych postępowań.

Jeśli chodzi o działalność TDBF we Francji, zastrzeżenia budzi jego niewielka aktywność orzecznicza wyrażająca się niewielką liczbą rozstrzyganych spraw. Rocznie wydaje on zaledwie kilka orzeczeń24 ${ }^{4}$. Jeśli

22 Do popełnienia czynu stanowiącego naruszenie dyscypliny finansów publicznych niezbędne jest popełnienie czynu wprost wymienionego w ustawie o odpowiedzialności za naruszenie dyscypliny finansów publicznych, która nie musi odwoływać się do ustaw odrębnych w celu określenia, jaki konkretnie czyn został popełniony. C. Kosikowski, Istota dyscypliny finansów publicznych..., s. 820.

23 J.M. Salachna, Odpowiedzialność za nieprzestrzeganie procedury tworzenia i wykonywania budżetu jednostki samorzq̨du terytorialnego, Warszawa 2008, s. 326.

24 Raport z działalności Trybunału za rok 2012 wskazuje, że od 1948 r. TBDF wydał 187 orzeczeń. Przykładowo w 2012 r. do TDBF skierowano 15 skarg, z czego 5 zgłosił Trybunał Obrachunkowy, a 9 regionalne izby obrachunkowe. W 7 przypadkach wydano orzeczenia, umorzono postępowanie w 9 przypadkach. W 2012 r. nie było przypadku uwzględnienia kasacji od orzeczenia TDBF, http://www.ccomptes.fr/ index.php/fr/Publications/Publications/Rapport-d-activite-2012 (dostęp: 11 grudnia 2013 r.). Wskazuje się, że od utworzenia Trybunału obserwuje się wzrost liczby kierowanych spraw: w latach 1950-1972 do TDBF skierowano 76 spraw, a w latach 
dodamy do tego, że część rozstrzygnięć dotyczy spraw nieposiadających istotnego znaczenia dla ochrony interesów finansowych państwa, a niekiedy czyny stanowiące naruszenie dyscypliny finansów publicznych są podejmowane w intencji ochrony interesów finansowych jednostek, których dotyczą, pytania stawiane o poprawność obecnej konstrukcji prawnej odpowiedzialności za naruszenie dyscypliny finansów publicznych w Polsce wydają się, również w świetle doświadczeń francuskich, zasad$n e^{25}$.

\section{Bibliografia:}

Borodo A., Polskie prawo finansowe. Zarys ogólny, TNOiK, Toruń 2010.

Kosikowski C., Istota dyscypliny finansów publicznych i odpowiedzialności za jej naruszenie, [w:] C. Kosikowski, E. Ruśkowski (red.), Finanse publiczne i prawo finansowe, Wolters Kluwer, Warszawa 2008.

La Cour des comptes, éd. Centre National de la Recherche Scientifique, Paris 1984.

Salachna J.M., Odpowiedzialność za nieprzestrzeganie procedury tworzenia i wykonywania budżetu jednostki samorzqdu terytorialnego, Wolters Kluwer, Warszawa 2008.

1973-1979, a więc w kilkakrotnie krótszym okresie, do Trybunału skierowano 72 sprawy. La Cour des comptes, op. cit., s. 917.

25 J.M. Salachna, Odpowiedzialność za nieprzestrzeganie..., s. 307-308, 326-327. 